\title{
Garudayana comic adaptation of the Mahabharata story series in the millennial era
}

\author{
I.D.A.D. Putra \\ Telkom University, Bandung, Indonesia
}

\begin{abstract}
Mahabharata comics, once popular in the 1950s-1970s, receded and sank in popularity because of the development of Japanese comics in the globalization era. During the sinking of Indonesian comics, the comic Garudayana emerged as a popular Mahabharata series among millennials. The success of these comics was due to the author's creative process in dealing with changes and challenges of the times. Reinterpretation and reduction of the Mahabharata story can be accepted and represent the tastes of readers of his era. Changes that were made, such as storyline, new characters, drawing style, and the right promotional strategies as keys to the success of the comic. This research used a qualitative method with data collection techniques through observation and literature study, as well as visual analysis to position the comic that can show the Mahabhatara story values and Indonesian identity.
\end{abstract}

Keywords: comics, Mahabharata, millennial

\section{INTRODUCTION}

Indonesian comics triumphed in the 1950s-1970s in various genres including the puppet genre with a comic artist named R.A. Kosasih. Kosasih was later considered the father of Indonesian wayang comics. Visualization or character figures in the Mahabharata comic created by R.A. Kosasih used the classic West Java Sundanese puppetry form approach, namely "wayang golek", "wayang wong", and ballet. The comic artist succeeded in merging puppet comics and Indonesian identity, which at that time were heavily influenced by American comics, with Western superhero characters. Even so, in Indonesia at that time there were already superhero comics, such as "Sri Asih", which was made by R.A. Kosasih who was influenced by the American comic "Wonder Woman" and "Garuda Putih" made by John Lo (Irena \& Andri 2017).

Entering the era of globalization in Indonesia, puppet comics are no longer known. Indonesia was flooded by the Japanese comic with its manga style. Japanese comics flooded Indonesia both physically, in the form of books, and digitally. Manga visualization was not only popular in the form of comics, but also in the form of animation, films, games, and other social media. This makes the millennial generation only recognize manga visuals. The millennial generation, born at that time, were crammed with manga visuals. They were also used to draw people at school, at home - everywhere was manga. Manga has become a meat in their minds, who shifted the visuals of American and European comics with their superheroes.

This development makes it appear that Indonesian comics have lost their identity and do not have reliable comic artists. In addition, the Indonesian people themselves have underestimated Indonesian comic artists. In 2009, the comic puppet Garudayana by comic artist Is Yuniarto appeared. It adopted the classic Mahabharata puppetry story from the first series, Adi Parwa. The story of Garuda in its classic version was changed through a contemporary approach with a simpler storytelling style by applying manga as a visual approach.

The Garudayana comic created by Is Yuniarto still can be said to be a success for a millennial version of the puppet comic with various publishing media. The success of this comic artist is the 
study in this paper. The aim of this paper was to see how the adaptation process of the Mahabharata story affected the comic industry, especially the first Parwa series, Adi Parwa, by Is Yuniarto in his Garudayana comic. It attemped to see if the adaptation of new characters and the creative process and strategy in introducing the comics made them become popular among millennial Indonesian youth.

\section{METHOD}

The research of this paper was a study of the comic Garudayana by Is Yuniarto. Comics are one of the most popular visual-based information media in the millennial generation. This study used qualitative methods through data collection techniques such as observation, literature study, and visual analysis. The qualitative method according to Bogdan and Taylor in Ratna (2016) does not merely describe, but more importantly find, the results and meanings contained behind them, as hidden meanings or intentionally hidden.

The qualitative method in turn produces descriptive data in the form of words, both written and oral. Furthermore, this method is used to explore and express the behavior or characteristics of millennial society, because the comics created by the comic artist were born in that era. Strengthening the background and any phenomena contained in the change in Garudayana comics can be done through literature study, by observing objects in the form of a Garudayana comic book series that has been made, and by analyzing visuals, especially classical puppets and new characters as well as aspects and rules contained in comic theory.

The description of the Garudayana comic was done by taking some of the visuals in the comic, from the creation process, as well as in terms of the promotion strategy in making this comic popular among millennial generation. The visualization of the Garudayana comics included aspects of general comic principles and particularly manga comics principles, story problems, and setting that makes the comic unique from other comics.

\section{RESULT AND DISCUSSION}

Comics as a medium of information and entertainment are closely related to the readers' tastes. The taste or interest in comics in each era or generation are different. Interest or taste in reading comics cannot be separated from the development of scientific and technological advances, which can change readers' behavior as consumers. In the development of comics in Indonesia, a trend in visualization style will emerge that also adapts to the current tastes preferred by the market. The flow of the market tastes always depends on the genre of interest, and the genre that is in demand by the market is always changing in every decade or era. The fate of this reading depends on the readers' temporary fondness for a genre (Boneff 1998). This statement proves that the trend of comics development in Indonesia fluctuates. Readers' tastes are strongly influenced by a trend of the genre that they are interested in and are also influenced by the comic industry which is stronger and has a wider market.

The millennial generation is a generation term that is currently being discussed by many people in the world in various fields. Millennials are also known as the Millennial Generation or Generation $\mathrm{Y}$ as a demographic group after Generation X. Social researchers often classify generations born between the 1980s and 2000s as millennials (Naldo \& Satria 2018). Compared to the previous generation, Generation X, the millennial generation is indeed unique. The research results released by the Pew Research Center in 2010, for example, in detail explain the uniqueness of the millennial generation compared to the previous generation, namely in the use of technology, pop culture, and music.

The life of the millennial generation cannot be separated from technology, especially the internet, or entertainment which has become a necessity for this generation. The birth process of the 
millennial generation has given birth to the generation of gadgets, a term used to mark the emergence of the millennial generation. Gadgets are more appropriate to be interpreted as equipment, where the generation of gadgets is meant to be the generation in life that has always been in contact with something called equipment containing elements of information technology. Various pieces of equipment including high-technology tools are an inseparable and important part of their lives (Wahana 2015).

The situation above explains the characteristics of the millennial generation, where the comic artist Garudayana is part of that generation. Is Yuniarto, born on June 22, 1981, certainly understands the world of millennials as he has been connected to the world of the internet from a young age. Visual pop culture such as manga in various media such as films, games, webtoons, comics, and animation became the author's aesthetic experience. These conditions and situations gave Is Yuniarto an advantage, in addition to his natural talent for drawing.

The Mahabharata puppet comic has also been popularized by R.A. Kosasih and several Indonesian comic artists such as S. Ardisoma, Oerip, Suherlan, N. A. Giok Lan, and others. R. A. Kosasih created 22 volumes of Mahabharata, 5 volumes of Bharatayudha, 4 volumes of Pandawa Seda, and 4 volumes of Parikesit. Ardisoma created Wayang Purwa which explained the initial story of the gods and the Bharata family in 22 volumes. He also created the story of the beginning of the Ramayana and Arjuna Sasrabahu and other stories (Sunarto 2013). These two comic artists created the basic understanding of Mahabharata and Ramayana and are used as references by other comic artists.

The Garudayana comic made by Is Yuniarto only used the background of the classic Mahabharata story and modified it into a new version tailored to the needs of the millennial generation. The Garuda comic story is not made like the classic story of the great epic. The comic artist is more generalized in essence; it is about heroism, about good and evil. The story in the comics was made simpler in several book series with smaller page counts, considering that millennials like practical and short things.

The story of the Garudayana puppet comic created by Is Yuniarto tells the story of Garuda, out of Adi Parwa's standard. The comic artist preferred to make his own story line as well as create new characters such as "Kinara" and "Garu" which are not found in the classic version. In addition, the author also made a new background setting that is closer to the places in Indonesia. All aspects in the Garudayana comic follow the comic aspects in the Japanese manga.

The contribution of Japanese popular culture such as manga to Indonesian comics began to appear in the 1980s and have increasingly dominated it since the 1990s. Comic artists who were born in the 1980s-2000s made manga the main reference which eventually gave birth to Indonesian comics in today's manga style. The influx of manga influences in Indonesia was also strengthened by the entry of the Japanese animation industry which is commonly known as anime. Is Yuniarto is very familiar with his socio-culture as well as his drawing talents that represent his era.

The Mahabharata story in the Garudayana comic is only the trigger for the story. The comic artist takes the general philosophy of the Mahabharata story that tells good and evil or "Dharma" versus "A-Dharma". The stories and characters that are presented tell more about how to struggle and fight against monsters, as well as other evil characters. The comic artist Is Yuniarto has successfully interpreted and reduced the Mahabharata story to get closer to the tastes of millennial readers. The story is simple and does not raise the value of the puppet philosophy, which makes it easier for Generation Y to digest.

Reinterpretation and reduction of the understanding of the classic Mahabharata story through comics is accompanied by a superficiality of meaning, compared to the shadow puppets show where the puppeteer can play with, using nuance, one word to broach complex problems. Shadows display the mysteries and complexities of life, inviting people to go beyond the limits of appearance. While the lines in the comics stop the movement of the soul, it is impossible to rival the mastermind. The comic artist made something that is realistic, the comic artist's clear 'imagination' (Boneff 1998). The weakness of a comic can be described properly. Images can inform something imaginary or dreamy. The reader's power of the imagination is lost. 


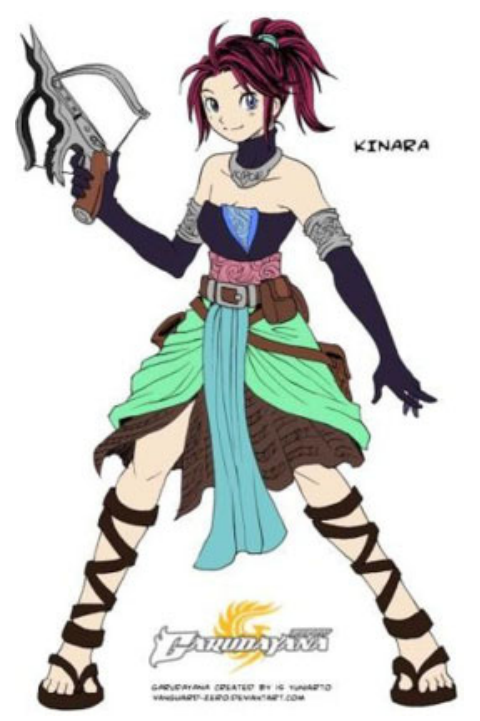

Figure 1. The new character of the creation "Kinara" by Is Yuniarto. (Source: deviantart.com/vanguardzero/art/Garudayana-Comic-Cover).

The comic artist had Garudayana's foresight toward female teenage millennial readers and created a character in the form of "Kinara". This character was made in an effort by the comic artist to attract female teenage millenial readers. "Kinara" is a new character created by Is Yuniarto, as he is very familiar with the stories and characters in the Mahabharata. The character "Kinara" was made by combining several elements contained in the female shadow puppet (putri) figure such as kamben, necklaces (badong), bracelets, ear ornaments, etc., while maintaining a manga-style depiction. Then the image of the weapon used by the "Kinara" character is heavily influenced by games and movies (see Figure 1).

The Garudayana comic also uses references to other characters in the style of shadow puppets, as well as page decorations using traditional decorative elements, in an effort to elevate the multicultural nature of Indonesian culture. In making the background, the comic artist includes several cultural houses in Indonesia. Like the shape of the Gadang house, and the shape of the Toraja house in Indonesia. This effort was made in addition to introducing Indonesian culture, as well as promoting comics for having Indonesian identity.

\section{CONCLUSION}

Garudayana comics made by Is Yuniarto are popular among millennial adolescents. It has lifted the Indonesian comic industry during the onslaught of the Japanese comic industry with its anime. Many Indonesian millennials did not know and weren't familiar with the puppetry comics that told the story of Mahabharata; they were more familiar with stories and characters in manga comics, as well as other entertainment media such as games, films, and music.

Garudayana comics can give readers a comic that is in line with the behavior or the habits of millennials with aspects that exist in manga which has been the trend of the decade. The Mahabrataha story interpreted and reduced by Is Yuniarto can provide a story that represents the comic trend of the era and lift the image of puppetry that gives identity to Indonesian comics.

Is Yuniarto is a comic artist who was born and grew up in the millennial era which resulted in his being able to cope with its development. Besides being a comic artist, he is also an entrepreneur who can read the market's tastes. Utilizing the effectiveness and efficiency of digital media, the 
promotion carried out succeeded in making the Garudayana comics favored by the millennial generation.

\section{ACKNOWLEDGMENTS}

The author would like to greatly thank PPM Telkom University for granting this research in basic and applied research programs.

\section{REFERENCES}

Boneff, Marcel. 1998. Indonesian comics (translation of Rahayu S. Hidayat). Jakarta: Gramedia's Popular Library.

Irena and Andri. 2017. Effects of Foreign Comics on Visualization of the Development of Comics in Indonesia. Journalof Magenta, STMK Trisakti 1(01).

Naldo Satria, Hardika Widi. 2018. Observation Study of the Use of Line Applications by Millennials. Journal of Social Applied Humanities 1(1).

Ratna, Nyoman Kutha. 2016. Research Methodology Cultural Studies and Social Sciences Humanities in General. Yogaykarta: Student Library (Matter II).

Sunarto, Wagiono, 2013. Visual Transformation of Mahabharata Figure. Journal of Stage Arts \& Culture 23(1). Wahana, Heru Dwi. 2015. The Effect of Millennial Generation Cultural Values and School Culture on Individual Resilience (Study at SMA Negeri 39, Cijantung, Jakarta). Journal of National Resilience XXI(1):14-22 